\begin{abstract}
Iranica
Abstracta Iranica Revue bibliographique pour le domaine irano-aryen

Volume 32-33 | 2013

Comptes rendus des publications de 2009-2010
\end{abstract}

\title{
Holger Wienholz. Ein hellenistisches Kapitell in Baalbek?
}

\section{Vito Messina}

\section{(2) OpenEdition \\ 1 Journals}

\section{Electronic version}

URL: http://journals.openedition.org/abstractairanica/40591

DOI: 10.4000/abstractairanica.40591

ISSN: 1961-960X

Publisher:

CNRS (UMR 7528 Mondes iraniens et indiens), Éditions de l'IFRI

\section{Printed version}

Date of publication: 1 December 2013

ISSN: 0240-8910

\section{Electronic reference}

Vito Messina, "Holger Wienholz. Ein hellenistisches Kapitell in Baalbek? », Abstracta Iranica [Online], Volume 32-33 | 2013, document 209, Online since 01 July 2016, connection on 27 September 2020. URL : http://journals.openedition.org/abstractairanica/40591 ; DOI : https://doi.org/10.4000/ abstractairanica.40591

This text was automatically generated on 27 September 2020.

Tous droits réservés 


\title{
Holger Wienholz. Ein hellenistisches Kapitell in Baalbek?
}

\author{
Vito Messina
}

\section{REFERENCES}

Holger Wienholz. « Ein hellenistisches Kapitell in Baalbek? ». ZOrA, 3, 2010, p. 88-100.

1 The only known Hellenistic capital from Baalbek has been reused in an eastern row of columns supporting the vaults of the so-called Friday Mosque. On the basis of stylistic criteria, it has been dated to the first century BC. It is what remains of a period, otherwise nearly unattested on the site, that reached its apogee under the Roman Empire. The piece is unusual not only because of its form, which according to the author reveals an acanonical design, but also owing to the questions it arouses about the original context. It is important evidence about the presence on the site of buildings decorated with architectural elements realized by using general Hellenistic criteria, but also evidence of a lax attitude in this part of the Levant toward about how to use the prescribed forms during the period immediately before Imperial times.

\section{AUTHORS}

VITO MESSINA

Università di Torino 